\title{
LINGUISTICS
}

DOI: https://doi.org/10.33739/2587-5434-2021-3-1-11-25

\section{LINGUOCULTURAL FEATURES OF THE NUMBER NINE}

\author{
Zoia Adamia \\ Doctor of Philology, Professor \\ Institute of Russian Language and Literature \\ Tskhum-Abkhazian Academy of Sciences \\ (Tbilisi, Georgia) \\ email: a.zoia777@gmail.com \\ Manana Shelia \\ Doctor of Education, Associate Professor \\ Sokhumi State University \\ (Tbilisi, Georgia) \\ e-mail: manan-7@mail.ru \\ Maia Marghania \\ Doctor of Philology, Associate Professor \\ Sokhumi State University \\ (Tbilisi, Georgia) \\ e-mail: maiko margania@mail.ru
}

\begin{abstract}
Abstarct. The paper deals with the study of language and culture - symbolic meanings of numbers via cognitive and linguocultural approaches. By means of these approaches we can find valuable information about mentality of the people with their life, history and culture drawing our attention to intercultural communications contributing to the development of cognitive interests.

Linguocultural studies provide a chance for learners to reflect their own language and culture, through the experience with foreign language and culture. The special attention is focused on the linguistic materials related to the linguocultural features of number nine in the Georgian, English and Russian languages and considerable linguistic and extra-linguistic parallels are made between the languages.

Comparative studies and analysis of genetically unrelated languages are significant and actual researching their distinctions and similarities.

The linguocultural analysis of languages studying phraseological units expresses cultural and valuable priorities of various peoples. In phraseological fund of any language there is a certain quantity of phraseological units with different concepts. They connect with actually linguistic reality, open new possibilities of research of major linguistic aspects of a language.

Linguocultural and comparative study of British, Georgian and Russian numerals with national codes let language learners respect peoples and feel proud of their history, traditions and culture.
\end{abstract}

Keywords: language, culture, symbol, linguo-cultural, number nine, the Bible, linguistic, phraseological units 


\title{
ЛИНГВОКУЛЬТУРНЫЕ ОСОБЕННОСТИ ЦИФРЫ ДЕВЯТЬ
}

\author{
Зоя Адамия \\ Доктор филолгии, профессор \\ Институт русского языка и литературы \\ Цхум-Абхазская Академия наук \\ (Тбилиси, Грузия) \\ e-mail: a.zoia777@gmail.com \\ Манана Шелия \\ Доктор педагогики, ассоциированный профессор \\ Сухумский государственный университет \\ (Тбилиси, Грузия) \\ e-mail:manan-7@mail.ru \\ Майя Маргания \\ Доктор филологии, ассоциированный профессор \\ Сухумский государственный университет \\ (Тбилиси, Грузия) \\ e-mail: maiko_margania@mail.ru
}

\begin{abstract}
Аннотация. Статья посвящена изучению языка и культуры - символических значений чисел с помощью когнитивных и лингвокультурных подходов. С помощью этих подходов мы можем найти ценную информацию о менталитете людей с их жизнью, историей и культурой, повышая наше внимание к межкультурным коммуникациям, которые способствуют развитию когнитивных интересов.

Лингвокультурные исследования дают возможность учащимся через опыт общения с иностранным языком и культурой отразить свой собственный язык и культуру. Особое внимание уделяется лингвистическим материалам, связанным с лингвокультурными особенностями цифры 9 в грузинском, английском и русском языках, и проводит значительные лингвистические и экстралингвистические параллели между указанными языками.

Сравнительное изучение и анализ генетически несвязанных языков, фактически, в современной лингвистике исследуют их различия и сходства.

Лингвокультурный анализ языка учитывает изучение фразеологических единиц, в которых выражены культурные и ценностные приоритеты этноса. В фразеологическом фонде любого языка имеется определенное количество фразеологических единиц с различными понятиями. Различные понятия как единицы, связанные с собственно лингвистической реальностью, открывают новые возможности исследования важнейших лингвистических аспектов языка.

Лингвокультурное и сравнительное изучение британских, грузинских и русских цифр с национальными кодами позволяет изучающим язык с уважением относиться к народу и гордиться его историей, традициями и культурой.
\end{abstract}

Ключевые слова: язык, культура, символ, лингвокультура, число девять, Библия, лингвистические, фразеологические единицы

INTRODUCTION. The language as a cultural phenomenon, its evolution is closely related to culture and the relationship between them is studied in linguoculturology as a part of cognitive linguistics. V. N. Maslova states "Language is a product of culture, an important part of it and the condition of existence as a factor in the formation of cultural codes." (Маслова 2001, 7). 
The study of vocabulary in the national-cultural aspect allows the penetration of other linguistic and cultural communities into the world and the correct use of linguistic means taking into account the national-cultural specifics. F. Humboldt recognized the direct connection between language, thought, and the culture of peoples. He points out: "Language is closely intertwined with the spiritual development of mankind and accompanies it at all stages of local progress and regression, and reflects itself at all stages of culture" (Humboldt 1985, 48).

The cultural background, with its specificity, contains important information about the country, reflects the worldview of peoples represented in mythology, fairy tales, proverbs, sayings and folklore.

\section{Linguocultural aspect of interrelation of language and culture}

The linguocultural approach particularly focuses on the aspect of intercultural components. Culture is one of the fundamental concepts of social-humanitarian cognition.

Comparing languages, we can see differences in various fields of linguistics, language history, culture, traditions, conventions, habits, etc. Linguocultural analysis of linguistic units allows us to reveal the mental characteristics of the society and national-cultural specifics.

According to Maslova: "Every national linguocultural society is defined by a set of cultural connotations. Therefore, cultural connotations are not only information about the distinguishing characteristics of certain people, but also a high appreciation of linguistics" (Maslova 1997, 208).

The nations of the world are distinguished by their own history, culture, traditions and habits. "Cultural connotations can be an indicator of belonging to any cultural and ethnic group, people" (Benveniste 1974).

The linguocultural aspect of English, Georgian and Russian national-cultural components, vocabulary, phraseological units reflects folklore, religious concepts, history, culture and traditions of the peoples and it is very important to understand the language better.

Comparative linguoculturology is aimed at studying the peculiarities of national culture through other languages, particularly to understand and assimilate national-cultural information. E. Sapir states"Comparison is an ancient form of intellectual activity" (Sapir 1921, 155).

\section{PURPOSE, TASKS OF THE PAPER}

The purpose of the paper is to study and analyze the perception symbolics of the number nine on linguocultural aspect and their usage in biblical expressions, proverbs, sayings and idioms based on the Georgian, English and Russian language materials.

Key objectives to be achieved:

- Characterization of various linguocultural approaches to the problem of the number nine;

- Determining the symbolic meanings of the number nine in various cultures;

- Defining the number nine meanings in folklore, poems and spells;

- Comprehensive analysis of the number nine semantics in phraseological units - Biblical expressions, proverbs, sayings and idioms; 
METHODS AND TECHNIQUES OF THE STUDY. The methodological basis of the paper is determined by the object of the study itself. The symbolic imagination of the number nine takes a rather large place in phraseologies.

During the research we mainly used semantic, linguiocultural, cognitive and comparative analysis methods, identifying similarities and differences in symbolic meanings conveyed by numbers in the three cultures.

When studying digital phraseology, it is expedient to consider the symbolism of numbers and determine how much the Georgian, English and Russian peoples' national perception of symbolic concepts coincides in their speech.

\section{PRESENTATION OF THE BASIC MATERIAL - Universal notion of numbers}

Numbers, their properties and role were highly valued all over the world. They originate in astrology. In ancient times, some numbers were associated with ideas about surrounding objects, such as the Moon, the Sun.

As it is known numerology is the ancient field about numbers. According to the founder of numerological theories, the Greek mathematician and mystic Pythagoras and his followers, numbers are divided into two groups: light and dark numbers, good and evil numbers, numbers that bring happiness and misfortune, they think numbers govern human destiny. astroblogi.com/бyдjпммmмzos/

The life of any person and culture is encoded in numbers. According to numerological analysis, each of us has a destiny and abilities associated specifically with our own date of birth.

Throughout the ages numerical symbols have been formed in the course of long cultural and social factors. Therefore, the symbolism of numbers is the object of cultural studies and requires thorough investigation from cultural and ethnographic, linguocultural and semantic aspects.

All languages are symbolic systems that make use of symbols to convey meanings. Numbers can acquire a symbolic character thanks to complex historical-cultural associations.

As is well known, the symbolism of numbers is reflected differently in world cultures. Humans have been observing planets and stars since time immemorial and at the same time performing mathematical calculations (Losev 1988, 232-233).

The Babylonians in Mesopotamia started one of the oldest numbering systems, about 5,000 years ago. The Babylonians had a very advanced number system even for today's standards. They divided the day into twenty-four hours, each hour into sixty minutes, and each minute to sixty seconds.

Arabic numerals appeared in India probably in the 5th century. At the same time, the number "zero" was formalized and explained. Traditional Arabic numerals are a variant of Indian numerals used in the Arabic script.

The Chinese established one of the oldest systems of numerals that were based on sticks laid on tables to represent calculations.

The Roman numerical system is still used today. The Roman numerals are used to represent numerical chapters of books or for the main divisions of outlines.

In ancient times marked the ancient alphabet with numbers. Alphabet letters along with quantitative characteristics are based on the foundation of the numerical representation of the major divine values of the universe. The Iberian theosophical mathematics should be studied in the Georgian language and alphabet.

Greek numerals are a system of representing numbers using letters of the Greek alphabet. The Greek alphabet was adopted from the Phoenicians about the year 700 B.C. When the Phoenicians 
invented the alphabet, it contained about 600 symbols. The Greeks borrowed some of the symbols and made up some of their own. But the Greeks were the first people to have separate symbols or letters to represent vowel sounds. The word "alphabet" comes from the first two letters, or numbers of the Greek alphabet -- "alpha" and "beta." "Both the Hebrews and the Greeks used their alphabet as their written numeral system, with the result that words acquired numerical values" (Ferber 2007, 142)

The number association as a form of special culture of language belongs to a cultural association. The digital culture is widely presented in the countries of the world and its peculiarity has the features in Russian Georgian and British cultures. Magic numbers were reflected in oral folk art, including proverbs and sayings.

\section{Symbolism of the number nine among different religions and cultures}

In numerology, nine is considered a main number. Nine is a number of heaven, eternity, spirituality. It is a symbol of wisdom, harmony, courage, strength and good leadership.

It should be noted that the number "nine" played a major role in the numerical symbols of various religious traditions and cultures.

There are 9 planets in the solar system: Mercury, Venus, Earth, Mars, Jupiter, Saturn, Uranus, Neptune and Pluto. Every day is protected by its planet. The number nine is an image of the three worlds (earth, heaven and hell).

The nine-pointed star may symbolize nine great religions of the world: Bahá'i, Buddhism, Christianity, Hinduism, Islam, Jainism, Judaism, Shinto and Shikhism.

The human body is made up of nine major organs: brain, heart, lungs, stomach, intestines, liver, kidneys, bladder and skin. www. astromeridian. ru/magic/numerologija 3700.html

Nine worthy people of ancient times and the Middle Ages are distinguished in world history The Nine Worthies, which are traditionally divided into three triads: pagans: Hector, Alexander the Great, Julius Caesar; In the Old Testament of the Jews: Jesus Navin Joshua, David - David, Judas Maccabeus; Knight Christian heroes: King Arthur, Charlemagne, Godfrey of Bouillon. A beautiful 19 meter high fountain from the $14^{\text {th }}$ century has sculptures of the Nine Worthies. It is located in Nuremberg, Germany.

In Christianity the number nine is sacred and best known as cosmic number of angels. Various works of Cristian theology have devised hierarchies of angelic beings. Nine is a symbol of the Virgin Mary.

In Orthodox Christianity for Russians and Georgians, nine is an unfortunate number because in their minds nine is connected with religion and death (the soul leaves the body on the ninth day after death).

In Catholicism a novena is the act of saying prayers for nine consecutive days. The prayers of novena are of urgency and for a special and specific cause. The name "novena" comes from the Latin word "novenus", meaning "nine each".

The Roman numeral IX Templars denoted Jesus (I) King (X). The Templars were Christians during the medieval era, in other words they were members of the Poor Knights of Christ and of the Temple of Solomon, a religious military order of knighthood. Their mission was to protect Christian travelers and pilgrims visiting sites in the Holy Land.

For the Hebrews nine is a symbol of truth. The Hanukkah menorah, also chanukiah or hanukkiah is a nine-branched candelabrum lit during the eight-dayholiday of Hanukkah. Eight of the nine branches hold lights (candles or oil lamps) that symbolize the eight 
nights of the holiday; the ninth branch holds a candle, called the shamash ("helper" or "servant"), used to light the other eight. The word Hanukkah means"dedication" in Hebrew. The light represented the way God illuminates life, reveals hidden things and knows the intentions of the heart. The power was not in the candles; it is in God.

There are mentioned nine angels' choirs, and in the church art angels are usually divided into three spheres, the first sphere angels: Seraphim, Cherubim, Throne; angels of the second sphere: Dominations or Lordships, Virtues or Strongholds, Powers or Authorities, third sphere angels: Principalities or Rulers, Archangels, Angels.

The Ennead were the nine great Osirian gods:Atum, Shu, Tefnut, Geb, Nut, Osiris, Isis, Set and nephthys. The term is also used to describe the great council of the gods as well as a collective term for all the gods. The Ennead (a word derived from Greek, meaning the nine) is a grouping of nine deities, most often used in the context of Egyptian mythology.

The nine Muses of Greek mythology have appeared in many different modern fictional works. The list of Muses consists of: Calliope, the Muse of epic poetry; Clio, the Muse of history; Erato, the Muse of love poetry; Euterpe, the Muse of music; Melpomene, the Muse of tragedy; Polyhymnia, the Muse of hymns; Terpsichore, the Muse of dance; Thalia, the Muse of comedy; Urania/Ourania, the Muse of astronomy. In Atlantis, according to the description of Plato, there were 9 kingdoms. Deucalion, the Greek Noah, sails during 9 days on the vessel which he has built on the command of the gods. For Hesiode, the Earth was separated from the Heaven by a distance of nine days and nine nights, and from the hell also by nine days and nights.

Nine is a significant number in Norse Mythology. Odin hung himself on an ash tree for nine days and nughts to learn and secure rúnar 'runes, secret knowledge'. Odin's ring Draupnir releases eight golden drops every ninth night, forming rings of equal worth for a total of nine rings. The giant Baugi had nine thralls who killed each other in their desire to possess Odin's magical sharpening stone.

Every ninth year, people from all over Sweden assembled at the Temple at Uppsala. There was feasting for nine days and sacrifices of both men and male animals according to Adam of Bremen. There are nine surviving deities of Ragnarök, including Baldr and Hödr, Magni and Modi, Vidar and Váli, Hoenir, the daughter of Sól and a ninth "powerful, mighty one, he who rules over everything (Lindow 2001).

The Russian philosopher, philologist A. Losev noted the following events related to the number nine in ancient symbolism: 9 muses (its end in the 10th year), the Trojan War lasted 9 years, Odysseus traveled for 9 years, Phoenix spent 9 days in captivity at his parents' house, Poseidon spent 9 years with the sea goddess, nine trouble in the Achaeans by order of Apollo nine days of flooding in the Achaean camp. The children of Niobe are not buring for nine days, the dispute of the gods over the body of Hector is going on for nine days. For 9 days they mourned Hector and so on. Thus, Homer often uses 9 digits (Losev 1988, 232-233).

The Ninth Wave is a painting by a famous Russian marine painter Ivan Aivazovsky. It is his best-known work. It depicts a sea after a night storm and people facing death attempting to save their lives by clinging to debris from a wrecked ship. Ancient Greek sailors called the third wave fatal, ancient Roman sailors the tenth, but the ninth caused real horror among most representatives of other states. They say that in his life the painer Ivan Aivazovsky suffered some of what he saw himself. In 1844, he was destined to survive a severe storm in the Bay of Biscay, after which the ship on which the painter was staying was considered sunken, and a regrettable message appeared in the press that a famous young artist had also died during the storm. Thanks to this episode, and not a photo, Aivazovsky creates the picture "9 Shaft," which has become a world picturesque masterpiece. 
Indian numerologists believe that nine is a special number. In Hinduism nine is the number of Brahma, the Creator. In India it is believed that there are 9 stones to protect a person. Important Buddhist rituals usually involve nine monks.

The number "nine" was significant primarily in the ancient Egyptian cosmology where the gods were grouped in the so-called "Pesedjet" - the oldest of the pantheons. The priests in the city of On (Heliopolis) placed god Atum at the top of this 'pantheon of nine'. Nine was the name of the sacred mountain of the Sun, for the ancient Egyptians. The term "Nine Bows" was used in ancient Egypt that represented the enemies of Egypt. Hieroglyphic signs of the Nine Bows are found on the base of thrones, under the feet of statues of kings and also on the sandals of Tutankhamen.

In Chinese numerology since ancient times, emperors have associated themselves with the number 9 and tried to use it everywhere in life. Also, the nine is found in the Temple of Heaven. The floor of the main altar consists of rings, and in the first ring there are 9 tiles, in the second 18, in the third 27, and so on. The emperors of China wore a ceremonial dress depicting nine dragons. The Chinese empire was called the "nine continents," which meant "the whole world."

For the Mongols this is a sacred number. Sacrifice ceremonies are held on the ninth day of May and nine mares are gathered and blessed.

The number nine isn't quite so lucky in Japan. When number nine is pronounced, it sounds like the word for "pain". (Turner 2020).

\section{The phraseological units identifying the Georgian, British and Russian national consciousness}

Although we are dealing with radically different cultures and languages, there are obvious similarities in terms of the phraseological units that convey the physical and mental state of a person. Since cultural-linguistic transfer is less likely in the case of English-Georgian-Russian this proves that there are universal human values that all private cultures describe from their prism and often coincide completely with different cultures.

The analysis of language and culture without phraseological data would be incomplete, because it reflects the linguistic and cultural characteristics of the speakers of this language. (Gowie 1998, 57).

The linguocultural research of the number nine and its peculiarities, symbolism, various associations, and semantic meanings are reflected in phraseological expressions.

The phraseology particularly clearly reflects the national and religious specifics of various peoples, national identity, their life-style, customs and traditions.

For centuries, people have created and maintained wise proverbs and sayings that have been passed down from generation to generation, reflecting life's culture, working conditions, and relationships with the world.

T. N. Fedulenkova calls phraseological units stable phrases with fully or partially reinterpreted meanings (Fedulenkova 2000, 146):

Proverbs and sayings are a widely used genre of folklore that vividly capture the generalized wisdom created on the basis of historical experience.

The roots of the Georgian, British and Russian people are deeply embedded in the soil of their native countries. Georgian, British and Russian proverbs represent the thinking, mentality of the people living in the appropriate territories have been formed over many centuries.

Mythology of the British Isles deals with the stories, legends and folk-tales related to number nine. In pre-Christian times in Great Britain there were stories about nine women. The "Nine Maidens" folklore tradition in Scotland may be possible remnant of these earlier times. According 
to Scottish researcher Stuart McHardy, remaining stones once have been maidens who later turned to stone. There are a number of megalithic sites that are named "Nine Maidens" (Ralls-Macleod, Robertson 2005).

In Ancient English Anglo-Saxon mythology the universe (or rather multiverse) consisted on Nine separate worlds, supported by the World Tree, Éormensyll (>Ermensill)

1. Middangeard (>Midyard): "Middle Earth", the world of men that lies at the centre of the multiverse. 2. Ésegeard (>Esyard): The home of the Ése - one of the tribes of English Gods, including Wóden and Punor 3. Wenahám (>Wenham) : The home of the Wene (> Wanes), the other tribe of English Gods, including Neorðe (>Nertha), Freo and Frea. 4. Éottenhám (>Ettinham): Home of the Éottenas (> Ettins) or giants. 5. Helhám (>Hellham): Home of the dead and very much unlike its counterpart inChristianity. 6. Elfháf (>Elfham): Home of the Elves. 7. Sweartælfhám (> Swertelfham): Home of the Dark Elves. 8. Nifolhám (>Nifleham): The primordial World of Ice. 9. Múspelhám (>Mouspleham): The primordial World of Fire. englischerewulf.wordpress.com >

In Arthurian material, the best known of these groups are the Nine sorceresses, Moegan, and her sisters who live on the Isle of Avalon and are both seeresses and healers (Parry 1925).

In the Welsh tale of Peredur son of Efrawg, there are witches of Caer Lyowas well as in Welsh mythology there are nine maidens who tend the fire below the Cauldron of the "Chief of Annwn"; this cauldron is the target of Arthur's raid on the Underworld in Taliesin's famous poem Preiddeu Annwfn (Jones, 1993).

The later Anglo-Saxon Nine Herbs Charm mentions seven worlds, which may be a reference to an earlier pagan cosmological belief.

The Norse God Odin, ruler of the $\mathbf{9}$ Norse worlds, hung $\mathbf{9}$ days on the world axis or Yggdrasil tree to win the secrets of wisdom for mankind.

The frequency of British proverbs, sayings and idioms and their intensive use in speech reflects the reality, consciousness and thinking of people of different ethnic backgrounds living in the UK, representing the social and spiritual aspects of human activity. Let's consider a few British proverbs, sayings, and idioms.

Nine tailors make a man. Since this proverb appeared in print in William Hickes's Grammatical Drollery (1682), by the last quarter of the seventeenth century the phrase had become sufficiently popular to be recognized in a poem. There are different interpretations on this proverb. The story goes like this: A poor hungry boy in London arrives to hire a master tailor. He was picked up and given nine tailors to study. Each of them taught him the craft. The boy mastered the profession and opened a business himself and became very rich. He was traveling in his own carriage with a Latin inscription. Some people give an interpretation of the given expression as follows. In the old days, when one woman died, the church bell rang six times, but nine times when a man died. The bell that rang was called "Messenger". thus, "Nine Tellers Mark a Man." "Tailor" and "Mark" reached in a corrupted form. People misunderstood and that is why Nine tailors make a man came to us in this way.

The second word in this expression is a corruption of Tellers. A "Teller" was in olden times a stroke of the "passing bell" of the parish church. Three tellers gave warning of the death of a child, six of a woman, and nine of a man. As the parishioners counted the strokes they would say: "Nine tellers make a man.” (Benham, Gurney 1926)

A cat has nine lives. According to myth, in many cultures "a cat has nine (or sometimes seven) lives."As it is known, cats are elastict and try to avoid dangerous situations and can jump from any height. Cats can survive many accidents because they land on their paws without injury. 
Idiomatic expression is a complex lexical-grammatical and semantic linguistic formation. Extralinguistic and ethnolinguistic factors of both general and national nature played a great role in its formation, development and language establishment. Here the idioms pertaining to the number nine are offered:

Nine days' (or seven-day or one-day) wonder - An event which is a nine-day wonder causes interest, surprise or excitement for a short time, but it doesn't last.

Dressed to the nines and dressed to the teeth - Fig. dressed very stylishly with nothing overlooked. She showed up for the picnic dressed to the nines. Clare is usually dressed to the teeth in order to impress people.

Nine times out of ten - Fig. usually; almost always.

Nine-to-five job - a job with normal daytime hours.

Nine-to-five attitude: an approach to work in which an employee does the minimum required to remain employed.

On cloud nine - very happy. When I got my promotion, I was on cloud nine.

Possession is nine-tenths of the law - An ownership is easier to maintain if a person has possession of something and difficult to enforce if a person does not.

Stitch in time saves nine - Prov. If you fix a small problem right away, it will not become a bigger problem later.

Whole nine yards - the entire amount; everything, as far as possible (McGraw 2002).

As is known the Russian, English and Georgian (not an Indo-European family language) languages are not closely related languages; it can be found the thinnest nuances of sense of language units which can be most widely presented in biblical expressions.

Georgian folklore has preserved many expressions characterized by the number "nine" (nine

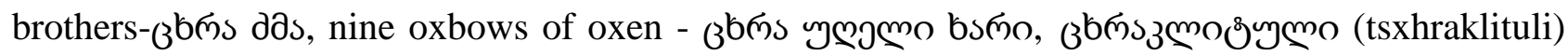
(Engl. Under seven seals) - a secret, impenetrable (place) lit under nine locks ("Who else has a

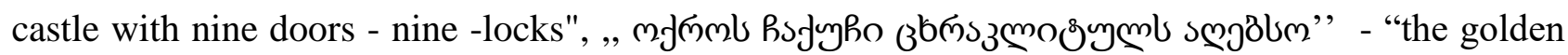
hammer opens nine-locks"), "nine mountains"- ( (

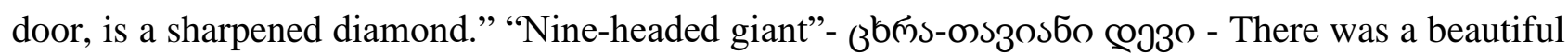
woman who said to the sun: come down, I will come up, No one on the earth knew about this woman except one nine-headed giant.

The expression "nine mountains" is common in Georgian oral tradition. This expression

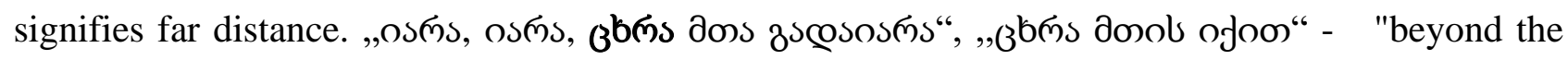

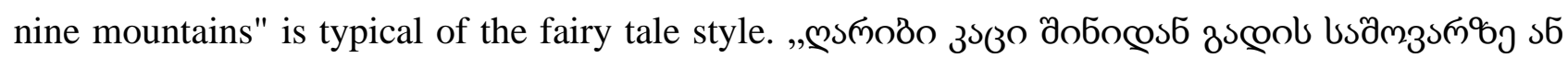

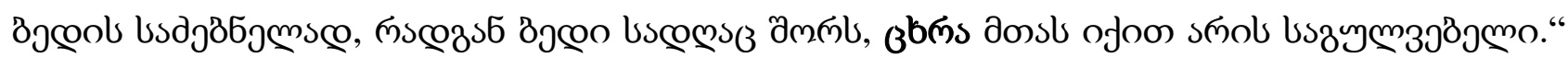

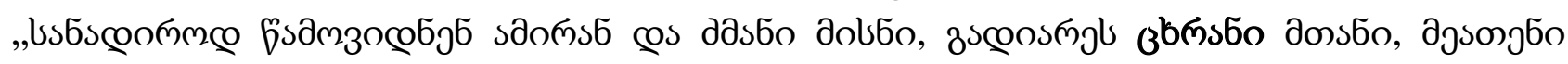

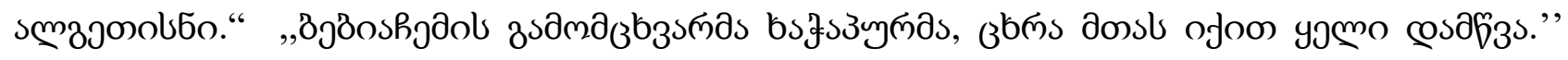

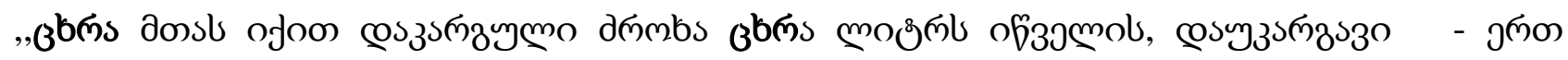

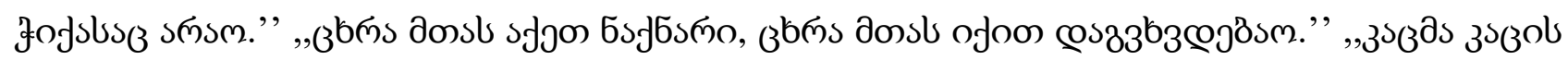

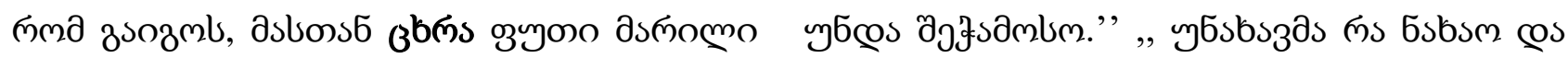

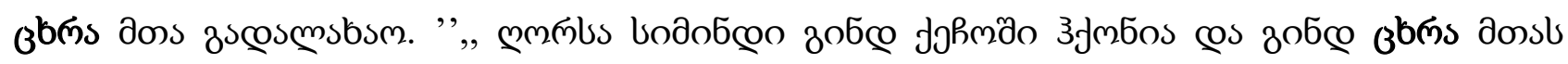

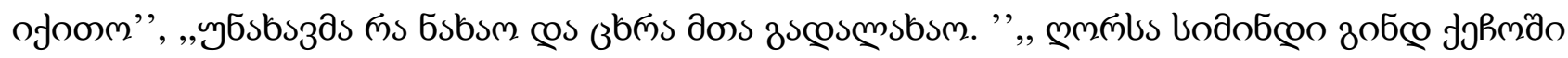

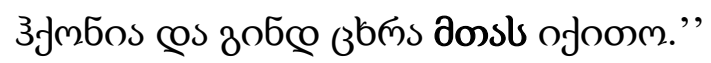

(hbjody 2002). 
Here are some other proverbs based on the number nine:

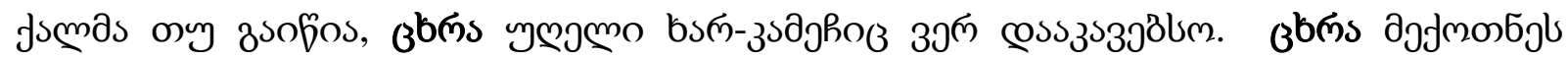

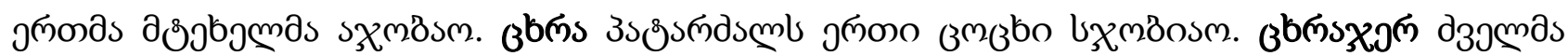

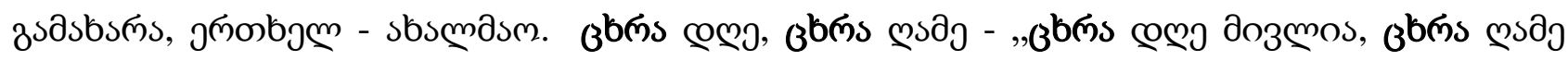

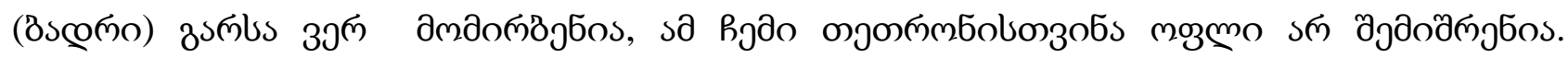

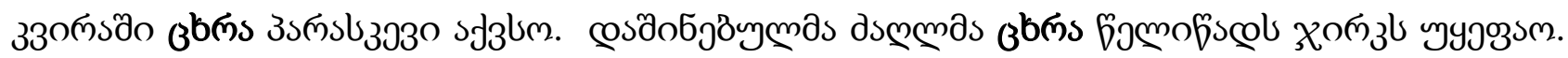

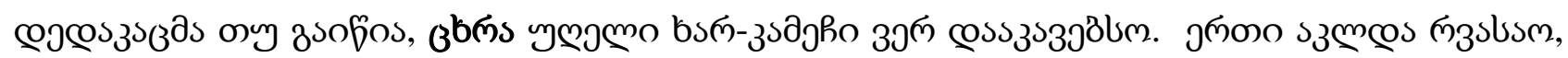

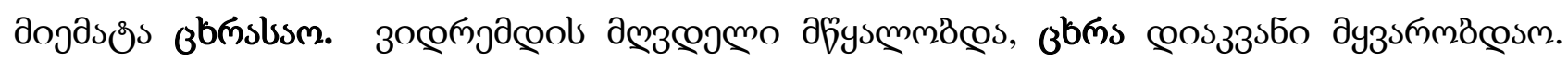

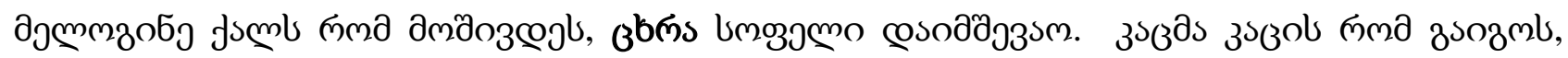

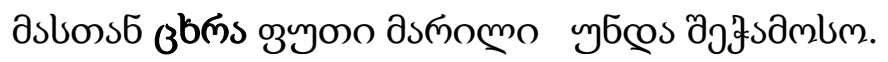

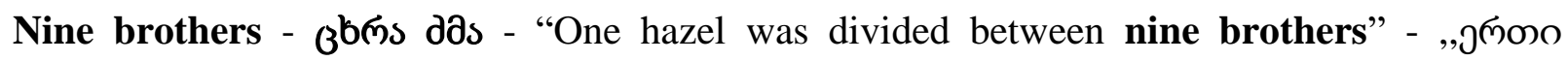

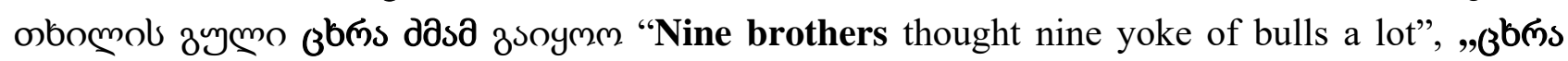

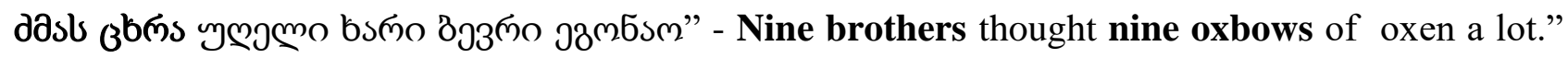

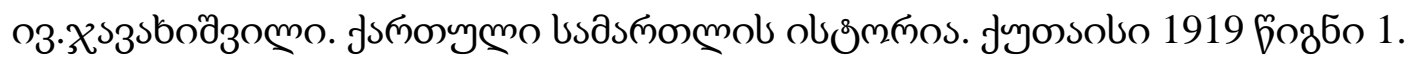

Here is one of the popular verses from Georgian folk poetry:

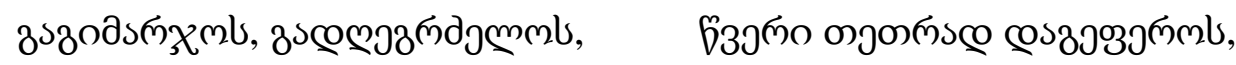

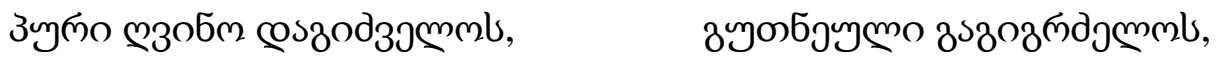

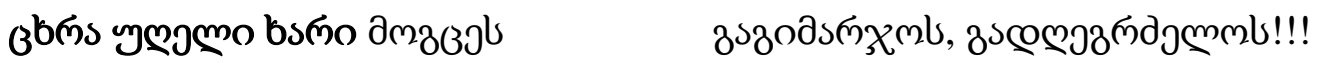

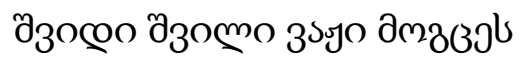

In Georgian folklore there is a popular story of the nine Kherkheulidze brothers' brave devotion that widely reflected in the Georgian folk literature. On July 1, 16259 brothers Kherkheulidz were killed in the battle of Marabda. A small army of Georgians could not cope with the experienced, Qizilbash fighters. When the ninth, youngest brother also knelt down, the flag was taken by their sister and after her death by the hero mother raised.

The Georgian poet Giorgi Tsereteli in the children's poem "Who Else Has Another" used the number nine in every stanza; here is a part of the poem:

ubzols zols sdals:

ऊbms dons,

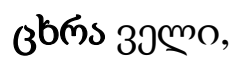

5sf65so -

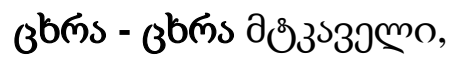

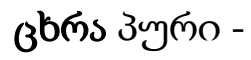

उbms daol bszosmo,

ऊbms basmo -

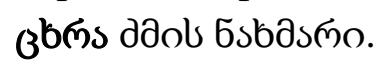

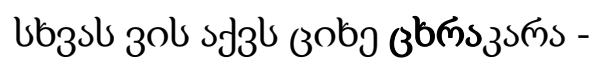

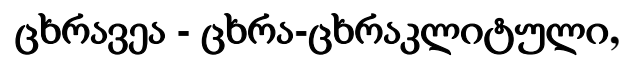

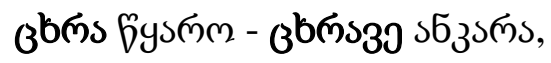

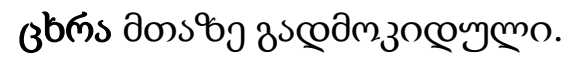

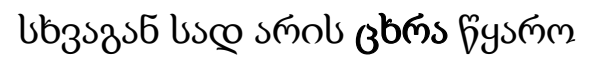

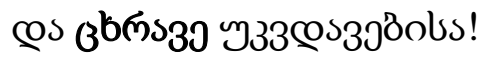

The number nine also has a magical function. Georgian folklore is rich in spells. A spell is a figurative, linguistically rich form of folklore that is considered an archaic genre. The words spoken by a person during a spell have magical powers and are directed against harmful spirits. This time we are part of a happy prayer.

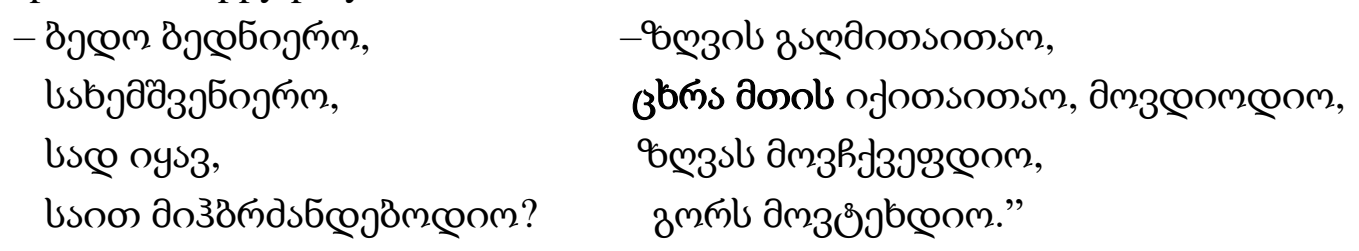


In Alexander Abashidze's poem "Nine Sources" the number nine is mentioned six times:

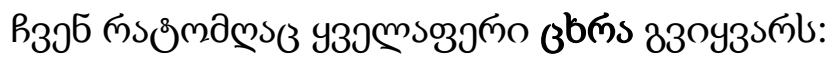

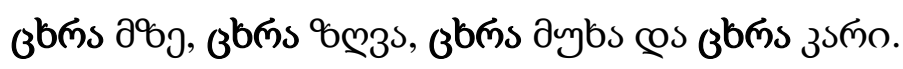

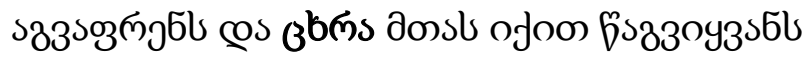

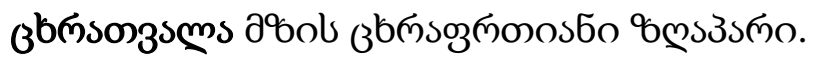

In Slavic symbolism nine is the number of Death, transition to the other world, a symbol of the transition from one state to another, or from bodily death to other forms of life. This is a fundamental change in human Genesis, death in one world and birth in another.

In Ancient Russia, among the Slavs 9 days a week, 9 months a year is used to be believed that nine colours are seen by a person. "Nine" is closely connected precisely with the moon, communication with the souls of the dead, enchantment, etc.

The number nine is very often found in Russian folk culture. The Russian fairy tale "In the Kingdom behind Nine Mountains” - „В тридевятом царстве" describes the "different, distant, magical" country, separated from the usual world by dense forest, abyss and sea. It is a collection in which the main characters move from one fairy tale to another. The kingdom is associated with the ideas of the Slavs about the otherworld as a country of abundance. The epic of different peoples surrounding Russia is reflected in fairy tale form.

Number nine often appears in magical texts and rituals (especially medicinal ones), where 9 pebbles, 9 slivers, 9 coal, water from 9 wells, etc. are used. Serbian recipe: „Найди 9 никогда не кошеных лугов и когда на них вырастет трава высотой в 9 пальцев, собери 9 парней, пусть они ее скосят новыми косами, а 9 девушек пусть их соберут новыми вилами, потом это сено надо варить в 9 новых чанах, этой водой помойся и тогда выздоровеешь".

Spells from the "nine ailments" were certainly read in the Slavic charlatanic herbal medicine and elecampane- девятисил (девясил) was considered one of the most powerful herbs.

The Russian people have a lot of proverbs and sayings. They transfer from age to age, from one generation to another. The largest collection of proverbs belongs to Vladimir Ivanovich Dahl. The ancient Russians attributed mysterious power to the number nine that is sometimes good or evil. "Nine" is not often observed in Russian proverbs and sayings.

Бык стоит девяносто рублей, спесивый человек и девяти копеек не стоит. Всем по семь, хозяину восемь, хозяйке - девять, что ровно делит. Девять мышей вместе потянули крышку с кадушки стянули. Девять человек - все равно что десяток. Из десяти монахинь девять - блудницы, а одна не в своем уме. У храбреца десять доблестей: одна отвага, девять - ловкость. Уступив однажды, девять раз останешься в выигрыше. Девять человек - всё равно, что десяток. Бык стоит девяносто рублей, спесивый человек и девяти копеек не стоит. Чудо длится только девять дней.

\section{The features of connotative meanings of the number nine in the Bible}

In Christianity, the symbolism of numbers was less developed before the teachings of Saints Augustine and Alexander. According to St. Augustine, numbers are the archetype of the Absolute.

The Bible is a sacred book of Christians, the outstanding phenomenon, the highest spiritual essence of world culture enriched with philosophical expressions.

Language of the Bible has huge impact on formation of the literary languages of many peoples since ancient times acquainted with Christian culture. The translations of the Holy Writ into 
national languages became a basis of book languages of Europe, including Slavic. Thus that commenting of the text of the Bible is one of the most ancient and most traditional occupations of the philologists, many aspects of this difficult perspective should be referred to the little developed. Questions of specifics of assimilation by concrete languages of those elements which go back to the Bible text, about nature of their further development in each of these languages, etc. are that, in particular (Mokienko 2003, 114).

The Bible contains a lot of number symbolisms. The number 9 is used 49 times in the Bible. Nailed on the cross, Jesus Christ died at the ninth hour of the day. OR $3 \mathrm{pm}$. Jesus appears nine times to his disciples and apostles after his resurrection.

The Day of Atonement (Yom Kippur) is the only one of God's annual Feast days of worship that requires believers to fast for one day. This special day, considered by many Jews to be the holiest of the year, begins at sunset on day 9 of the seven Hebrew month (Leviticus 23, 32).

The number 9 represents the Fruit of God's Holy Spirit which is a biblical term that sums up nine attributes of a person or community living according to the Holy Spirit. Galatians $\mathbf{5}$ is the fifth chapter of the Epistle to the Galatians in the New Testament of the Cristian Bible. It has teachings by Paul and contains a discussion about circumcision and the allegory of the "Fruit of the Holy Spirit". The fruit of the Spirit is love, joy, peace, long-suffering and kindness, goodness, faithfulness, gentleness, self-control and against such there is no law (Galatians 5:22-23). biblehub.com > galatian

Nine gifts of the Holy Spirit 8 To one there is given through the Spirit a message of wisdom, to another a message of knowledge by means of the same Spirit, 9 to another faith by the same Spirit, to anothe gifts of healing by that one Spirit, $\mathbf{1 0}$ to another miraculous powers, to another prophecy, to another distinguishing between spirits, to another speaking in different kinds of tongues, and to still another the interpretation of tongues. (1 Corinthians 12: 8-10).

The ninth beatitude (Matthew 5:11-12) refers to the bearing of reviling and is addressed to the disciples. The word beatitude comes from the Latin beatitudo, meaning "blessedness."

In the Revised Standard Version, the nine Beatitudes of Matthew 5:3-12 read as follows:

1. Blessed are the poor in spirit, for theirs is the kingdom of heaven. 2. Blessed are those who mourn, for they shall be comforted. 3. Blessed are the meek, for they shall inherit the earth.4. Blessed are those who hunger and thirst for righteousness, for they shall be satisfied. 5. Blessed are the merciful, for they shall obtain mercy. 6. Blessed are the pure in heart, for they shall see God. 7. Blessed are the peacemakers, for they shall be called sons of God. 8. Blessed are those who are persecuted for righteousness' sake, for theirs is the kingdom of heaven. 9. Blessed are you when men revile you and persecute you and utter all kinds of evil against you falsely on my account. Rejoice and be glad, for your reward is great in heaven, for so men persecuted the prophets who were before you.

Jesus died 9 hour after the crucifixion. "It was nine in the morning when they crucified him." (Mark $15: 25$ )

"There be nine things which I have judged in mine heart to be happy, and the tenth I will utter with my tongue: A man that hath joy of his children; and he that liveth to see the fall of his enemy:" King James Version (KJV)

"The first battle mentioned in God's word is between a confederation of 4 kings against another which has 5 kings for a total of 9" (Genesis 14:1 - 2).

"In was at the 9th hour of the day that a Roman Centurion named Cornelius was told, in a vision, to contact the apostle Peter. Cornelius would eventually be baptized and receive God's spirit, becoming the first recorded Gentile convert to Christianity" (Acts 10). 
"In the twelfth year of Ahaz king of Judah, Hoshea son of Elah became king of Israel in Samaria, and he reigned nine years" (2 Kings 17:1)

"Og king of Bashan was the last of the Rephaites. His bed was decorated with iron and was more than nine cubits long and four cubits wide. It is still in Rabbah of the Ammonites" (Deuteronomy 3:11) NIV

CONCLUSIONS. In the paper we have made linguocultural and comparative analysis of number nine symbolism in the British, Russian and Georgian digital cultures. We could find valuable information about mentality of the people with their life, history and culture.

The linguocultural approach also helps language learners to respect other people's cultures and values, in solution of business, common problems on obtaining and studying of cognitive materials. We aimed at revealing similarities or differences between lexical and phraseological units.

The different language world - Georgian, English and Russian phraseologiacal units: proverbs, sayings and idioms express the same meanings but in a different way, as for a structural-semantic sense we find much common as they convey the familiar concepts characteristic to individual nations. Life of biblical expressions in the modern European languages convincingly testifies to imperishability of spirit and a letter of the Book of books. Phraseological units in three languages adapting bible words and expressions that made them own language property.

Thus, it should be noted that phraseological units make the concentrated wisdom of all nations. The results of linguocultural and comparative analysis demonstrated that numbers within Georgian, British and Russian proverbs, sayings and idioms can evoke similar as well as different associations for the three nations. The number nine may intensify positive as well as negative feelings, emotions or actions.

\section{LIST OF REFERENCES}

Adamia, Z., Shelia, M., Marghania, M. (2020). Comparative analysis of biblical phraseological units with blue and green colour components (on the example of English, Russian and Georgian) // Tom 2 № 44 (2020): Naukovii visnik Uzhgorodskogo universitetu. Seriya Filologiya, pp.17-27. DOI: https://doi.org/10.24144/2663-6840.2020.2.(44).17-27

Balmond Cecil (1998). "Number 9, the search for the sigma code" Prestel 2008

Benham, W. Gurney (1926). Putnam's Complete Book of Quotations, Proverbs, and Household Words. New York: G.P. Putnam's Sons.

Cowie A. P. (1998). Theory, Analysis and Applications; Oxford Studies in Lexicology. Oxford: Clarendon Press.

Fedulenkova, T. \& Adamia, Z. (2019) Seven frequent models in biblical phraseology of modern English // International Scientific-Pedagogical Organization of Philologists "WEST-EAST " (ISPOP). Scientific Journal WEST-EAST. Vol 2/1 N1 (October, 2019). p.p. 17-23. doi: https://doi.org/10.33739/2587-5434-2019-2-17-23

Fedulenkova, T. N. (2000) Angliyskaya frazeologiya /Arhangelsk: PGU, 2000. - 175

Ferber, M. (2007). A Dictionary of Literary Symbols. Cambridge: Cambridge University Press Lind Jones, G \& Jones T. (1993). The Mabinogion Everyman p164 Lindow, John (2001) Handbook of Norse mythology, Santa Barbara, Calif., Oxford University Press. ISBN 0-19-515382-0.

McGraw (2002) - Hill Dictionary of American Idioms and Phrasal Verbs. by The McGraw-Hill Companies, Inc. 
Mokienko, V. M. (2003). Bibleizmy v Evropeyskoy frazeologii I paremioloii. Moskva.

Karen Ralls-Macleod, Ian Robertson The Quest for the Celtic Key, 2005, e-Book, 2013, Luath Press, Edinburgh Parry, JJ. The Vita Merlini 1925, University of Illinois Press, p. 27.

Sapir 1949:155) Edward Sapir (1884-1939). Language: An Introduction to the Study of Speech.1921.

Turner, Bambi (2020). '13 Superstitions About Numbers', How Stuff Works

Gumboldt, V. (1985). Yazyk i filosofiya kultury. - M.: Progress.

Maslova, V. L. (2001). Lingvokulturologia, M.

Loseva, A. F. (1988). Istoria antichnoi estetiki. Poslednii veka. Kn. 1, M., s.231-233.

Loseva,A. F. (1969). Istoria antichnoi estetiki. Sofisti. Sokrat. Platon. M., s. 326, 313.

Chxeidze, E. (2002). Literaturuli dziebani 2002 №22 ricxvTa simbolika qarTul folklorshi.

Javakhishvili, I. (1919). QarTuli samarTlis istoria. QuTaisi 1.

Inglisuri andazebi da khatovani Tqmani. Shemdgenlebi I. Gvarjaladze da J. Mchedlishvili, gamomc. Marani, Tb., (1970).

www. International Version (NIV) - Bible Gateway

thekingsbible.com King James Version

\section{For citation:}

Adamia, Z., Shelia, M \& Marghania. (2021) Linguocultural features of the number nine // International Scientific-Pedagogical Organization of Philologists "WEST-EAST" (ISPOP). Scientific Journal WEST-

EAST. Vol 5 N1 (March, 2021). pp. 11-25. https://doi.org/10.33739/2587-5434-2021-3-1-11-25

\section{Для цитирования:}

Адамия, 3. К., Шелия, М., Маргания, М. (2021) Лингвокультурные особенности цифры девять // International Scientific-Pedagogical Organization of Philologists "WEST-EAST" (ISPOP). Scientific Journal WEST-EAST. Vol 5 N1 (March, 2021). C. 11-25. https://doi.org/10.33739/2587-5434-2021-3-1-11$\underline{25}$

Information about the authors:

Zoia Adamia - Doctor of Philology, Director of the Institute of Russian Language and Literature at TskumAbkhazian Academy of Sciences, inviting professor at Sukhumi State University, Deputy Director of the International Scientific-Pedagogical Organization of Philologists "WEST-EAST", Georgia.

e-mail: a.zoia777@gmail.com

Manana Shelia - Doctor of Education, Associate Professor, Sokhumi State University, Institute of Foreign Languages at Tskum-Abkhazian Academy of Sciences, Georgia.

e-mail: $\underline{\text { manan-7@mail.ru }}$

Maia Marghania - Doctor of Philology, Associate Professor, Sokhumi State University, Institute of Foreign Languages at Tskum-Abkhazian Academy of Sciences, Georgia.

e-mail: maiko_margania@mail.ru

\section{Сведения об авторах:}


Зоя Адамия - доктор филологии, директор Института русского языка и литературы Цхум-Абхазской Академии наук, приглашенный проф. Сухумского государственного университета. Заместитель директора международной научно-педагогической организации филологов «Запад-Восток», Грузия. e-mail: a.zoia777@gmail.com

Манана Шелия - доктор педагогики, ассоциированный профессор, Сухумский государственный университет, Институт иностранных языков Цхум-Абхазской Академии наук, Грузия.

e-mail: manan-7@mail.ru

Майя Маргания - доктор филологии, ассоциированный профессор, Сухумский государственный университет, Институт иностранных языков Цхум-Абхазской Академии наук, Грузия.

e-mail: maiko_margania@mail.ru

Manuscript received: 14/01/2021

Accepted for publication: $15 / 02 / 2021$

Рукопись получена: 14/01/2021

Принята к печати: 15/02/2021

International Scientific-Pedagogical Organization of Philologists "West-East" ISPOP

SCIENTIFIC JOURNAL "WEST-EAST"

ISSN (print) - 2587-5434 ISSN (online) - 2587-5523 